\title{
Physical Attacks: \\ An Analysis Of Teacher Characteristics Using The Schools And Staffing Survey
}

Thomas O. Williams, Jr., Virginia Tech, USA

Jeremy V. Ernst, Virginia Tech, USA

\begin{abstract}
This study investigated physical attacks as reported by public school teachers on the most recent Schools and Staffing Survey (SASS) from the National Center for Education Statistics administered by the Institute of Educational Sciences. For this study, characteristics of teachers who responded affirmatively to having been physically attacked in the past 12 months were examined. Teacher characteristics associated with being physically attacked appeared to be proportionate to those found in the general population of teachers who were not physically attacked. Several notable exceptions were gender, school type, years of experience, and school location. The mean number of physical attacks varied greatly within all characteristics examined. Of the twelve teaching areas, special education had the highest percentage of teachers who reported being physically attacked in the past 12 months and the highest mean number of physical attacks per teaching area.
\end{abstract}

Keywords: SASS; Schools and Staffing Survey; Violence; Teacher Attacks; Teacher Characteristics

\section{INTRODUCTION}

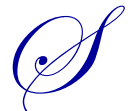

chool violence is a prominent topic in professional journals and the general media. It is also an issue of great concern to federal, state and local education agencies (Robers, Kemp, Rathbun, \& Morgan, 2014). While students are primarily the focus of this research and the subject of school-wide intervention strategies, students are not the only ones victimized or subjected to violence in schools. Teachers are also subjected to threats and physical attacks; usually with the students as the perpetrators. Although violence affects everyone within a school, there is a lack of research on school violence that is primarily directed at teachers (Espelage et al., 2013; McMahon et al., 2007). Most of the research to date on school violence has focused on student-on-student violence; leaving a void in research concerning violence directed towards teachers (Espelage et al., 2013; McMahon, et al., 2014).

Although there is limited empirical and theoretical information related to violence perpetrated towards teachers and teacher exposure to school violence, the trend suggests that the problem of threats and attacks is increasing or, at the very least, remaining consistent over time. The Schools and Staffing Survey (SASS) series, administered by the Institute of Educational Sciences, has questions addressing violence and threats directed toward teachers. The SASS series also addressed working conditions relating to teacher welfare and safety, as well as whether they have been threatened or physically attacked by a student from their school. Two questions specifically asked teachers if they had been threatened or physically attacked in the previous 12 months. Nine percent of public school teachers reported being threatened with injury by a student from their school during the 2011-2012 school year. While this percentage was lower than the 12 percent who reported to the SASS administration of being threatened with violence in 1993-94, it was higher than the 2003-2004 and 2007-2008 administrations report (7 percent each). The percentage of teachers reporting that they were physically attacked by a student from their school was five percent in 2011-2012. This percentage was higher than previous survey cycles from 2003-2004 and 2007-2008 survey years which reported percentages ranging from three to four percent (Dinkes, Cataldi, \& Lin-Kelly, 2007).

Teachers are presented with a wide variety of issues that they must address in the classroom in addition to their basic academic responsibilities. Aside from day-to-day administrative and academic tasks, teachers also manage a wide 
variety of social and behavioral issues that can impact the classroom environment (Williams \& Ernst, 2016). In the 2012 SASS report, 38 percent of teachers agreed that student misbehavior interfered with their teaching (Dinkes, Cataldi \& Lin-Kelly, 2007). Violence and physical assault are two student misbehaviors that can have a deleterious effect on teaching effectiveness and teacher morale. Violence against teachers can also produce physical and emotional effects, as well as diminished teaching-related functioning (Wilson, Douglas, \& Lyon, 2011). Teachers who feel unsafe tend to show a reduced commitment to their educational task (Vettenburg, 2002). If teachers feel unsafe or anxious about their safety in the classroom, it could have a potentially adverse effect on their ability to ensure student safety, welfare, and academic performance.

\section{RESEARCH QUESTION}

Considering the general absence of detailed information associated with public school teacher characteristics associated with physical attacks, this investigation was launched to construct a national profile of teachers who reported being physically attacked over the course of the past 12 months. This research addressed the following questions.

1. What are the characteristics of teachers who reported being physically attacked in the past 12 months? Specifically:

a. What is the impact of gender?

b. What is the impact of race and ethnicity?

c. What is the impact of highest degree obtained?

d. What is the impact of teaching status (full, part-time)?

e. What is the impact of certification status (fully certified, other)?

f. What is the impact of licensure route (alternative, traditional)?

g. What is the impact of experience (beginning $<$ three years experience, experienced $>$ than three years experience)?

h. What is the impact of school location (rural, town, suburban, urban)?

i. What is the impact of school type (elementary, middle, high, and combined)?

j. What is the impact of being highly qualified?

$\mathrm{k}$. What is the impact of main teaching assignment?

\section{METHODOLOGY}

\section{Instrumentation}

The Schools and Staffing Survey (SASS) is conducted by the National Center for Education Statistics (NCES) and administered by the Institute of Educational Sciences (IES) on behalf of the U.S. Department of Education to collect extensive data on American public and private elementary and secondary schools. The SASS provides data on the characteristics and qualifications of teachers and principals, teacher hiring practices, professional development, class size, and other conditions in schools across the nation. The overall objective of SASS is to collect the information necessary for a comprehensive picture of elementary and secondary education in the United States. The amount and type of data collected permits detailed analyses of the characteristics of schools, principals, teachers, school libraries, and public school district policies. The SASS was designed to produce national, regional, and state estimates for public elementary and secondary schools as well as related components. "Therefore, SASS provides a multitude of opportunities for analysis and reporting on elementary and secondary educational issues." (p.1, Tourkin, Thomas, Swaim, Cox, Parmer, Jackson, Cole, \& Zhang, 2010).

The SASS consists of five questionnaires: a School District Questionnaire, Principal Questionnaire, School Questionnaire, Teacher Questionnaire, and a School Library Media Center Questionnaire. This study analyzed data from the SASS Teacher Questionnaire (SASS TQ). The purpose of the SASS TQ was to obtain information about teachers, such as education and training, teaching assignment, certification, workload, and perceptions and attitudes about teaching. 
There were in total 85 questions in the SASS TQ comprised of nine sections along with additional NCES frame and created variables that are only available on the restricted-use data file. Variables were classified as frame variables if they were drawn from or based on the SASS sampling frame. "Created variables are based on survey variables, frame variables, other created variables, or a combination of these. These variables are frequently used in NCES publications." (Appendix T-1; Tourkin, Thomas, Swaim, Cox, Parmer, Jackson, Cole, \& Zhang, 2010). These variables were added by the NCES to the restricted-use data files to facilitate data analysis and research.

\section{Procedures}

This study consisted of a secondary analysis of the SASS TQ dataset and follows the methodology of previous SASS TQ investigations by the research team (Ernst \& Williams, 2014; Ernst \& Williams, 2015; Ernst, Li \& Williams, 2014). Initial access was applied for and authorized by the NCES for a restricted-use data license. Specific protocol and reporting information was submitted and subsequently accepted by IES, where authorization was received for dissemination and release of the data findings.

Data were analyzed using SPSS 22.0. Descriptive data for research questions were weighted using the Teacher Final Sampling Weight (TFNLWGT) variable which is appropriate for descriptive statistics. The NCES and IES require that $n$ 's be rounded to the nearest 10 to assure participant anonymity. Therefore, data and percentages in tables and narrative may not add to the total $\mathrm{N}$ reported because of rounding requirements. In cases where an estimate did not meet the NCES or IES reporting standards (Robers, Kemp, Rathbun, \& Morgan, 2014), it was suppressed and noted in the table.

\section{Participant Selection}

This study examined data from both full and part-time public school teachers who completed the 2011-2012 SASS TQ survey. It included data for all teachers who reported being physically attacked in the past 12 months. Although two questions on the SASS TQ address physical attacks, for this study, data on physical attacks was limited to teachers who reported being attacked in the previous 12 months. This was done to facilitate accuracy in teacher reporting. It addressed the issue in a condensed timeframe as opposed to addressing attacks that could have occurred during a period ranging from 1 to 47 years based on the level of teaching experience within the sample.

\section{Variables Analyzed}

A detailed description of the variables analyzed is included in this section. The question number, question, whether the question was a created/frame variable, and response categories are given in this section. This was done to facilitate replication of the study and to clarify the variables under investigation. The variables chosen for analysis frequently occur in the literature concerning research on teacher induction, teacher mentoring, job satisfaction and teacher retention (Billingsley, Crockett, \& Kamman, 2014; Boe, Cook, \& Sunderland, 2007; Guarino \& Santibanze, 2006; Jones \& Youngs, 2012).

Teaching assignment area. The SASS TQ created/frame variable ASSIGN03 was used to group teachers for comparisons. The IES created this variable to categorize teachers into their main teaching assignments. ASSIGN03 consisted of 12 categories: 1) Early Childhood or General Elementary; 2) Special Education; 3) Arts or Music; 4) English and Language Arts; 5) ESL or Bilingual Education; 6) Foreign Language; 7) Health or Physical Education; 8) Mathematics; 9) Natural Science; 10) Social Science; 11) Vocational Career, or Technical Education, and 12) All Others.

Gender, race, and ethnicity. The gender of teachers was determined by SASS TQ question 78, "Are you male or female?" Respondents could choose either male or female. The race and ethnicity of teachers were determined by two questions on the SASS TQ. Question 80 asked, "Are you of Hispanic or Latino origin?" The respondents could reply either yes or no. Question 81 asked, "What is your race?" Respondents were to mark one or more of the listed races. The SASS TQ provided five choices for race: White, Black or African-American, Asian, Native Hawaiian or Other Pacific Islander, or American Indian or Alaska Native. Participants were allowed to select more than one racial category. 
Level of education. The SASS TQ created/frame variable HIDEGR was used to determine the highest degree obtained and held by the teacher. The five degree choices for this variable were Associate, Bachelors, Masters Education Specialist, and Doctorate and were used as the indicator for education level. This variable did not take into account multiple degrees (e.g. double Bachelors or double Masters). Only the highest degree obtained by the respondent was reported.

Employment status. Full and part-time employment status was determined by the SASS TQ created/frame variable FTPT. Respondents were asked whether they were employed on a full-time or part-time basis.

Certification status. The SASS TQ question 37a, "Which of the following describes the teaching certificate you currently hold that certifies you to teach in THIS state?" was used to identify whether or not the teachers were certified in the subject they teach. Four levels were provided. One being fully-certified. The reaming three choices represented degrees of certification or certification progress. We collapsed this variable into two levels to indicate whether the teachers were fully certified or not fully certified.

Certification route. The SASS TQ question used to determine whether the certification route was alternative or through a traditional college program was question 41, "Did you enter teaching through an alternative certification program?" "An alternative program is a program that was designed to expedite the transition of non-teachers to a teaching career, for example, a state, district, or university alternative certification program.” (p. 26, SASS: TQ). The respondent was requested to indicate either an alternative or traditional route to certification.

Qualification status. The SASS TQ question used to determine qualification status was question 42, "This school year, are you a Highly Qualified Teacher (HQT) according to your state's requirements?" This question was used to determine whether the teacher was presumed to be HQT. There were four choices ranging from highly qualified in all subjects to not sure of the status. "Generally, to be Highly Qualified, teachers must meet requirements related to 1) a bachelor's degree, 2) full state certification, and 3) demonstrated competency in the subject area(s) taught. The HQT requirement is a provision under the No Child Left Behind (NCLB) Act of 2001.” (p.26, SASS: TQ)

Geographic location and school type. The SASS TQ variable URBAND12 was used to identify the geographic location of schools. This variable allowed for four choices: Urban, Suburban, Town, and Rural. The SASS TQ variable SSCHLEVE2 was a four-category level of school based on grade levels offered as reported by the school. "Categories include: primary: schools with at least one grade lower than 5 and no grade higher than 8; middle: schools with no grade lower than 5 and no grade higher than 8 ; high: schools with no grade lower than 7 and at least one grade higher than 8; combined: schools with at least one grade lower than 7 and at least one grade higher than 8. Schools with only ungraded classes were included with combined schools." (Appendix T-17; Tourkin, Thomas, Swaim, Cox, Parmer, Jackson, Cole, \& Zhang, 2010).

Physical attacks. To determine physical attacks, the following two questions were chosen from the SASS TQ. Question 68a, "Has a student FROM THIS SCHOOL ever physically attacked you?" Question 68c, "In the past 12 months, how many times has a student FROM THIS SCHOOL physically attacked you?"

\section{RESULTS}

Descriptive analyses were used to illustrate differences in teacher characteristics that were related to those who reported being physically attacked in the past 12 months. The results of this analysis indicated that there was a large degree of variability in both the characteristics of those who were attacked and the mean number of times that teachers within those characteristics reported being attacked.

Table 1 shows the number and percentage of attacks concerning demographics. The percentage of public school teachers in each category are listed in the second column for comparison purposes. For example, $23.7 \%$ of all school teachers are male and of those teachers who were attacked in the past 12 months, $14.9 \%$ were male with a mean of 5.6 attacks. The percentage of male teachers who reported being physically attacked was disproportionately lower than the percentage of male teachers in the general teaching population. 
Teacher characteristics associated with being physically attacked appeared to be proportionate to the same characteristics as found in the general population of teachers who were not physically attacked with the exception of specific characteristics within race, gender, school type, experience, certification status, education level, and school location. While there is a degree of variability within these findings, they suggest that a likely candidate for being physically attacked would be a female, who is a beginning teacher, who teaches in an elementary school setting, and in a city school system.

Table 1. Attacks on teachers by selected demographics as reported on the SASS TQ.

\begin{tabular}{|c|c|c|c|}
\hline $\begin{array}{c}\text { Teacher } \\
\text { Characteristic }\end{array}$ & $\begin{array}{l}\text { Total Percentage in } \\
\text { Public Schools }\end{array}$ & $\begin{array}{l}\text { Percentage Attacked in the } \\
\text { Past } 12 \text { Months }\end{array}$ & $\begin{array}{l}\text { Mean Attacks in the } \\
\text { Past } 12 \text { Months }\end{array}$ \\
\hline \multicolumn{4}{|l|}{ GENDER } \\
\hline Male & 23.7 & 14.9 & 5.6 \\
\hline Female & 75.3 & 85.1 & 4.9 \\
\hline \multicolumn{4}{|l|}{ RACE } \\
\hline Hispanic & 7.8 & 5.7 & 4.1 \\
\hline White & 90.0 & $88 . .0$ & 5.3 \\
\hline Black/African American & 7.6 & 9.8 & 2.3 \\
\hline Asian & 2.2 & 2.2 & 6.9 \\
\hline Pacific Islander & 0.3 & $* *$ & $* *$ \\
\hline Native American & 1.4 & 1.2 & 2.8 \\
\hline \multicolumn{4}{|l|}{ SCHOOL TYPE } \\
\hline Primary School & 48.1 & 71.6 & 5.0 \\
\hline Middle School & 17.5 & 10.6 & 4.1 \\
\hline High School & 28.4 & 10.4 & 3.2 \\
\hline Combined & 6.1 & 7.3 & 8.5 \\
\hline \multicolumn{4}{|l|}{ LOCATION } \\
\hline City & 28.3 & 42.6 & 5.3 \\
\hline Suburb & 32.4 & 27.7 & 4.8 \\
\hline Town & 12.2 & 12.2 & 5.3 \\
\hline Rural & 27.1 & 17.7 & 4.1 \\
\hline \multicolumn{4}{|l|}{ EXPERIENCE } \\
\hline Beginning Teacher $<3$ years & 11.3 & 16.5 & 5.5 \\
\hline Experienced $>3$ years & 88.7 & 83.5 & 4.9 \\
\hline \multicolumn{4}{|l|}{ EMPLOYMENT } \\
\hline Full-time & 93.1 & 93.8 & 5.1 \\
\hline Part-time & 6.9 & 6.2 & 3.1 \\
\hline \multicolumn{4}{|l|}{ CERTIFICATION } \\
\hline Fully Certified & 91.3 & 89.8 & 4.6 \\
\hline Not Fully Certified & 8.7 & 10.2 & 5.6 \\
\hline \multicolumn{4}{|c|}{ CERTIFICATION PROGRAM } \\
\hline Alternative program & 14.6 & 15.0 & 5.1 \\
\hline Traditional program & 85.4 & 85.0 & 5.0 \\
\hline \multicolumn{4}{|l|}{ HIGHLY QUALIFIED } \\
\hline In all subjects taught & 72.7 & 73.2 & 4.7 \\
\hline In one subject & 7.0 & 6.0 & 4.2 \\
\hline None & 2.5 & 3.5 & 5.5 \\
\hline Not sure & 17.7 & 17.3 & 6.3 \\
\hline \multicolumn{4}{|l|}{ EDUCATION LEVEL } \\
\hline Associate & 3.8 & 3.7 & 8.3 \\
\hline Bachelor & 39.9 & 41.5 & 4.5 \\
\hline Master's & 47.7 & 43.7 & 5.4 \\
\hline Education Specialist & 7.6 & 10.4 & 4.4 \\
\hline Doctorate & 1.1 & $* *$ & $* *$ \\
\hline
\end{tabular}

Note: All $n$ 's rounded to the nearest 10 per IES requirements. ** Did not meet IES reporting standards. 
Table 2 shows the number and percentage of physical attacks concerning the main teaching assignment. The number and percentage of all public school teachers in each category are listed in the second column for comparison purposes. For example, 31.9 percent of all public school teachers are Early Childhood or General Elementary. Of those teachers, 6.6 percent reported being attacked in the past 12 months with a mean of 2.8 attacks per teacher. Special Education teachers reported the highest percentage (17.6) of attacks and the highest mean number of physical attacks (8.5). Elementary education teachers followed next with 6.6 percent of their teachers reporting being physically attacked. These findings indicate that there is a high degree of variability within teaching assignments concerning physical attacks.

Table 2. Main teaching assignment by attacks and the number of physical attacks reported in the past 12 months.

\begin{tabular}{l|c|c|c}
\hline \multicolumn{1}{c}{$\begin{array}{c}\text { General Field of Main Teaching } \\
\text { Assignment }\end{array}$} & $\begin{array}{c}\text { All Teachers in Main } \\
\text { Teaching Assignment }\end{array}$ & $\begin{array}{c}\text { Attacked in the Past } \\
\text { 12 Months }\end{array}$ & $\begin{array}{c}\text { Mean Attacks in the } \\
\text { Past 12 Months }\end{array}$ \\
\hline Early Childhood or General Elementary & $1079720(31.9)$ & $71110(6.6)$ & 2.8 \\
\hline Special Education & $430600(12.7)$ & $75830(17.6)$ & 8.5 \\
\hline Arts or Music & $203700(6.0)$ & $4940(2.4)$ & 1.9 \\
\hline English and Language Arts & $380740(11.2)$ & $9340(2.5)$ & $* *$ \\
\hline ESL or Bilingual Education & $70430(2.1)$ & $3910(5.6)$ & 2.9 \\
\hline Foreign Language & $98990(2.9)$ & $1230(1.2)$ & 1.1 \\
\hline Health or Physical Education & $180730(5.3)$ & $9600(5.3)$ & 2.3 \\
\hline Mathematics & $281990(8.3)$ & $5690(2.0)$ & 2.7 \\
\hline Natural Science & $226700(6.7)$ & $6360(2.8)$ & 1.4 \\
\hline Social Science & $209770(6.2)$ & $2940(1.3)$ & $* *$ \\
\hline Vocational Career, or Technical Education & $153280(4.5)$ & $2900(1.9)$ & 1.4 \\
\hline All Others & $68530(2.0)$ & $3530(5.1)$ & 3.3 \\
\hline Not & & \\
\hline
\end{tabular}

Note: All $n$ 's rounded to the nearest 10 per IES requirements. Percentages are in parentheses.

** Did not meet IES reporting requirements.

\section{DISCUSSION}

This study presented a descriptive analysis of teacher and school characteristics associated with being physically attacked as reported on the SASS TQ. Pertaining to teaching assignment, special education teachers were more likely to be physically attacked than their general education peers. They reported a higher ratio of physical assaults per teacher than teachers in the other teaching assignment areas. They also reported the highest mean number of physical attacks. This finding was consistent with previous studies (Williams, 2015; Williams \& Ernst, 2015).

Collectively speaking, teachers who reported being physically attacked in the past 12 months were predominantly white $(88.0 \%)$ and female $(85.1 \%)$. The attacks were more likely to occur in the primary/elementary school setting (71.6\%) and in city schools (42.6\%). Most of the teachers who reported being attacked were full-time (93.8\%), fully certified teachers $(89.8 \%)$, who took a traditional route to teaching licensure $(83.6 \%)$ and had a Master's degree or higher (56.4\%). Approximately $16.5 \%$ of those teachers who reported being physically attacked in the past 12 months were beginning teachers with three or fewer years' experience.

The percentages of those who were assaulted were generally in line with the characteristics of teachers who were not assaulted with the exception of males ( $8.8 \%$ lower), and females $(9.7 \%$ higher). The setting influenced attacks with the elementary setting ( $28 \%$ higher), having the highest level of attacks. While high school (18\% lower) and middle school (9.9\% lower) settings had lower levels of attacks. Beginning teachers with less than three years' experience (5.2\% higher) had higher levels of attacks. City schools (14\% higher) produced a higher level of attacks; with suburban (4.7\% lower) and rural schools $(9.4 \%$ lower) having fewer attacks. These findings suggest that professional development activities related to behavior management and crisis prevention may be beneficial for teachers who are beginning teachers, those who teach in an elementary school setting, and those working in city schools.

There are many potential costs related to school violence directed at teachers. These can be measured in economic terms such as lost days from work through sick days and workman's compensation claims for injuries. In addition, there are the medical costs, counseling costs, and higher insurance premiums associated with injuries. They can also 
be measured in professional capital loss concerning higher teacher turnover and the expense of training and replacing teachers who chose to leave the field due to the hostile working environment. Overall, violence directed toward teachers has far reaching consequences and has significant impacts on teachers in addition to the impacts on student performance.

\section{Limitations}

More research needs to be conducted concerning violence and threats directed toward teachers. A major limitation in the research thus far is that most information is self-reported. While there are studies that examine workman compensation records and crime reports, the majority are self-reported and therefore, subject to errors in recall and bias. Likewise, there is no official definition of what constitutes a physical attack or with the associated severity of the attack. For example, a student bumping into a teacher counts the same as a teacher stabbed with an object. As with all sample data, the estimates reported are subject to sampling error as well as to measurement and recording error. All estimates should be interpreted as approximate.

\section{AUTHOR BIOGRAPHIES}

Thomas O. Williams is an associate professor in the Special Education Program at Virginia Tech. His educational background is in psychology and special education/rehabilitation. He specializes in research focused on large scale data sets, disabilities in STEM, and issues related to psychoeducational assessment.

Jeremy V. Ernst is an associate professor in the Integrative STEM Education Program at Virginia Tech. His educational background is in technology and human resource development, technology education, and special education. He specializes in research focused on dynamic intervention means for STEM education students categorized as at-risk of dropping out of school.

\section{REFERENCES}

Billingsley, B. Crockett, J.C., \& Kamman, M. (2014). Recruiting and retaining high quality special education teachers and administrators. In Sindelar, P., Brownell, M., Lignugaris-Kraft, B., \& McCray, E. Handbook for Research on Special Education Teacher Preparation, Routledge, Taylor-Francis: New York, NY.

Boe, E. E., Cook, L. H., \& Sunderland, R. J. (2007). The prevalence of various aspects of teacher preparation, induction, mentoring, extra support, professional development, and workload factors for beginning teachers in general and special education. (Data Analysis Report No. 2007-DAR1). Philadelphia, PA: University of Pennsylvania, Graduate School of Education, Center for Research and Evaluation in Social Policy.

Dinkes, R., Cataldi, E.F., and Lin-Kelly, W. (2007). Indicators of School Crime and Safety: 2007 (NCES 2008-021/NCJ 219553). National Center for Education Statistics, Institute of Education Sciences, U.S. Department of Education, and Bureau of Justice Statistics, Office of Justice Programs, U.S. Department of Justice. Washington, DC.

Ernst, J.V. \& Williams, T.O. (2014). Technology and engineering education accommodation service profile: An ex post facto research design. Journal of Technology Education, 26(1), 64-74.

Ernst, J.V. \& Williams, T.O. (2015). The who, what and how conversation: Characteristics and responsibilities of current inservice technology and engineering educators. Journal of Technology Studies (41)1, 48-56.

Ernst, J.V., Li, S. \& Williams, T.O. (2014). Secondary engineering design graphics educator service load of students with identified categorical disabilities and Limited English Proficiency. Engineering Design Graphics Journal, 78(1), 1-10.

Ervasti J, Kivim“aki M, Pentti J, Salmi V, Suominen S, Vahtera J, Virtanen M. (2012). Work-related violence, lifestyle, and health among special education teachers working in Finnish basic education. Journal of School Health, 82, 336-343.

Espelage, D., Anderman, E. M., Brown, V. E., Jones, A., Lane, K. L., McMahon, S. D., Reddy, L. A., Reynolds, C. R. (2013). Understanding and preventing violence directed against teachers: Recommendations for a national research, practice, and policy agenda. American Psychologist, 68(2), 75-87. doi: 10.1037/a0031307

Guarino, C.M., Santibanez, L., \& Daley, G.A. (2006). Teacher recruitment and retention: A review of recent empirical evidence. Review of Educational Research, 76(2), 173-208.

Jones, N., \& Youngs, P. (2012). Daily emotions and their association with the commitment and burnout of beginning teachers. Teachers College Record, 114(2), 1-36.

McMahon, S. D., Martinez, A., Espelage, D., Rose, C., Reddy, L. A., Lane, K., Anderman, E. M., Reynolds, C. R., Jones, A. and Brown, V. (2014). Violence directed against teachers: Results from a national survey. Psychology in the Schools, 51, 753-766. doi:10.1002/pit21777

Robers, S., Kemp, J., Rathbun, A., and Morgan, R.E. (2014). Indicators of School Crime and Safety: 2013 (NCES 2014-042/NCJ 
243299). National Center for Education Statistics, U.S. Department of Education, and Bureau of Justice Statistics, Office of Justice Programs, U.S. Department of Justice. Washington, DC.

Tourkin, S., Thomas, T., Swaim, N., Cox, S., Parmer, R., Jackson, B., Cole, C., \& Zhang, B. (2010). Documentation for the 2007-08 Schools and Staffing Survey (NCES 2010-332). U.S. Department of Education. Washington, DC: National Center for Education Statistics. Retrieved June 17, 2014 from http://nces.ed.gov/pubsearch

Vettenburg, N. (2002). Unsafe feelings among teachers. Journal of School Violence, 1, 33-49

Williams, T.O. (2015, October). Characteristics of special education teachers who reported being physically assaulted. Poster presented at the International Education Conference, Las Vegas, NV, Session \#103.

Williams, T. O. \& Ernst, J. V. (2015, October). Are special education teachers more likely to be assaulted than other teachers? Published Proceeding of the International Education Conference, Las Vegas, NV, Paper \#368, p. 3681-3685.

Williams, T. O. \& Ernst, J. V. (2016). Characteristics of public school teachers who were physically attacked as reported on the School and Staffing Survey. Published Proceedings of the International Education Conference, Orlando, FL, Paper \#238, p. 2381-2385.

Wilson, C. M., Douglas, K. S., \& Lyon, D. R. (2011). Violence against teachers: Prevalence and consequences. Journal of Interpersonal Violence, 26, 2353-2371. 